wieku. Marian Pawlak natomiast podjął się porównania akademickich gimnazjów Elbląga, Gdańska i Torunia. Tom kończy studium Kazimierza Puchowskiego poświęcone modelowi kształcenia elit w szkolnictwie katolickim i protestanckim w Prusach Królewskich. Podobnie jak wcześniejsze tomy, również ten wyposażony został w indeks osób.

Omawiana publikacja jest kolejnym ważnym krokiem w badaniach nad dziejami edukacji w epoce nowożytnej. Tak ważna szkoła, jaką było Gdańskie Gimnazjum Akademickie, doczekała się wreszcie opracowania, na jakie zasłużyła. Grono wybitnych fachowców z zakresu dziejów oświaty, kultury, nauki podjęło się zbadania różnorodnych aspektów funkcjonowania szkoły zarówno od strony formalnej, ekonomicznej, przez programy, spuściznę i osobistości związane z działaniem szkoły do roli, jaką odgrywała ona w życiu miasta i regionu. Publikacja jest tym cenniejsza, że obok opracowań zamieszczono w niej również materiały źródłowe - pisane i ikonograficzne w doskonały sposób wzbogacające informacje zawarte w opracowaniach poszczególnych zagadnień.

\title{
Dorota Żoładź-Strzelczyk
}

\section{Elżbieta Magiera, Spóldzielczość jako forma edukacji w szkolnictwie polskim Drugiej Rzeczypospolitej (1918-1939), Wydawnictwo Naukowe Uniwersytetu Szczecińskiego, Szczecin 2011}

W roku 2011, nakładem Wydawnictwa Naukowego Uniwersytetu Szczecińskiego, ukazała się książka Elżbiety Magiery pt. Spółdzielczość jako forma edukacji w szkolnictwie polskim Drugiej Rzeczypospolitej (1918-1939). Jest to rozprawa, co należy z całym naciskiem podkreślić, o charakterze nowatorskim. Prace, które powstały do tej pory na temat spółdzielczości w kontekście edukacji Drugiej Rzeczypospolitej, posiadają charakter rozproszony i niekompletny. W tym kontekście książkę E. Magiery uznać można za pierwsze w historiografii polskiej tak pełne i syntetyczne opracowanie. Ukazanie się recenzowanej pracy było tym bardziej niezbędne, że uczniowski ruch spółdzielczy - jak zauważa we „Wstępie” sama Autorka - był w okresie międzywojennym masowy, a w dokonaniach na tym polu wyprzedzała Polskę tylko Francja (s. 10).

Struktura książki obejmuje siedem rozdziałów uzupełnionych o wstęp, uwagi końcowe, bibliografię, spis ilustracji oraz tabel.

„Uwagi wstępne” przedstawiają założenia metodologiczne omawianej rozprawy, precyzyjne określenie przedmiotu badań, wyjaśnienia terminologiczne i podstawy źródłowe. Uwagę odbiorcy zwraca szczególnie staranne uzasadnienie wyboru tematu, prezentujące nie tylko aktualny stan badań nad podjętym zagadnieniem, ale i wskazanie na potrzebę pochylenia się nad problemem uczniowskiego ruchu spółdzielczego. Potrzeba ta, co wyraźnie zauważa Autorka, nie wynika tylko ze wspomnianego już niedostatku badań w odniesieniu do okresu międzywojennego. Przywołanie polskiego dorobku w zakresie spółdzielczości wydaje się niezbędne zarówno w kontekście powojennej etatyzacji tej formy 
aktywności społecznej, jak i potrzeby ubogacenia współczesnego procesu budowania społeczeństwa obywatelskiego. Spółdzielczość, której immanentną częścią jest samorządność, inicjatywa i twórczość, jest tego społeczeństwa jednym z najważniejszych elementów.

Pierwszy rozdział pracy poświęcony jest genezie edukacji ruchu spółdzielczego, osadzając ją na trzech głównych filarach: dorobku europejskiego ruchu spółdzielczego w Europie Zachodniej XIX w. i na ziemiach polskich pod zaborami oraz uwarunkowaniach społeczno-pedagogicznych okresu międzywojennego. Ostatniemu z wymienionych determinantów poświęciła Autorka najwięcej miejsca, słusznie zakładając, że zarówno myśl pedagogiczna, jak i rozwój nauk pedagogicznych, socjologicznych i psychologicznych odegrał w rozwoju spółdzielczości Drugiej Rzeczypospolitej rolę wiążącą. Przypominając o inspirującej roli dwóch głównych w okresie międzywojennym ideologii wychowawczych, tj. pedagogiki narodowej i pedagogiki państwowej, Autorka dowodzi, że intensyfikacja edukacyjnego ruchu spółdzielczego przypadła na lata trzydzieste XX w. Nie jest to przypadek, gdyż właśnie przedstawiciele pedagogiki państwowej kładli nacisk na uspołecznienie jednostki, myślenie interesami państwa i społeczności, walkę z biernością i apatią. Dodać należy, że właśnie idea solidaryzmu społecznego, jak i kult pracy wynikający z piłsudczykowskiej filozofii czynu stał się podwaliną ideału wychowawczego sanacji ${ }^{1}$. Z tego względu interesujące badawczo byłoby podjęcie głębszych - niż zostało to ukazane w książce - rozważań na temat związku pomiędzy ideologią obozu Józefa Piłsudskiego a rozwojem spółdzielczości. Tłumaczyć to jednak można wielowątkowością podjętej problematyki i związaną z tym koniecznością selekcji podjętych tropów.

Udział w rozbudowie szkolnej spółdzielczości posiadał również nurt „nowego wychowania" i właśnie jemu poświęca Autorka najwięcej miejsca. Postęp w naukach biologicznych, filozoficznych i psychologicznych w połączeniu z potrzebami natury społeczno-ekonomicznej sprawił, że coraz chętniej sięgano do nowych metod wychowawczych, w tym i do tworzenia spółdzielczości uczniowskiej.

Istotną częścią omawianego rozdziału jest ta, w której Autorka dokonuje rozróżnienia nurtów polskiej myśli spółdzielczej: jednostkowego (liberalnego), solidarystycznego i neutralnego, z których - jak dowodzi - tylko ten ostatni miał praktyczne przełożenie na rozwój edukacji spółdzielczości. To właśnie przedstawiciele nurtu neutralnego (całościowego) opracowali podstawy gospodarcze, psychologiczne i społeczne spółdzielczości, wskazując jednocześnie na jej walory wychowawcze.

Kolejny rozdział pracy E. Magiery stanowi wprowadzenie ideologii spółdzielczej w ówczesną praktykę szkolną. Działalność spółdzielni uczniowskich jest tu pokazana na tle ustawodawstwa szkolnego, danych statystycznych, a także poglądów czołowych pedagogów i działaczy spółdzielczych okresu międzywojennego. Wartościowa pod względem poznawczym okazała się zwłaszcza prezentacja funkcjonowania poszczególnych spółdzielni szkolnych pod kątem organizacyjnym: rozwiązań w kwestii statutu czy spraw finansowych. Na tym przykładzie widać wyraźnie, w jaki sposób idea spółdzielczości

1 W. Paruch, Myśl polityczna obozu pitsudczykowskiego 1926-1939, Lublin 2005, s. 361. 
przygotowywała młodych ludzi do odpowiedzialności, zarządzania funduszami oraz współdziałania. Z tego powodu można powtórzyć za Autorką, że spółdzielnie uczniowskie należy postrzegać w kategoriach warsztatów pracy gospodarczej (s. 180).

Następne dwa rozdziały poświęcone są edukacji spółdzielczej na poszczególnych szczeblach szkolnictwa Drugiej Rzeczypospolitej: szkole powszechnej, szkole średniej ogólnokształcącej oraz szkole zawodowej. Przedmiotem rozważań są tu programy nauczania i wychowania poszczególnych szkół, w których uwypuklone zostały wszystkie te elementy, które odnosiły się wprost do idei spółdzielczości. Punktem zwrotnym w rozwoju spółdzielczości szkolnej okazała się być ustawa z 11 marca 1932 r., która uznając wychowanie gospodarcze i organizacyjne za podstawę wychowania państwowego, przyczyniła się tym samym do nadania spółdzielczości charakteru celowego i zorganizowanego działania. Na podkreślenie zasługuje fakt, że Autorka nie ograniczyła się tylko do analizy i interpretacji zagadnienia realizacji idei spółdzielczości w każdym z wymienionych rodzajów szkolnictwa, ale i dokonała wnikliwej oceny wynikających z tego tytułu różnic. Dowiadujemy się, że najbardziej podatnym gruntem dla rozwoju edukacji spółdzielczości były szkoły zawodowe, zwłaszcza rolnicze, co oczywiście można uzasadnić samym charakterem tego typu szkolnictwa. W porównaniu ze szkołami powszechnymi czy średnimi ogólnokształcącymi szerzenie postaw prospółdzielczych odbywało się nie tyle drogą popularyzacji, ale nabywania konkretnej wiedzy i umiejętności. Innymi słowy, stanowiło doskonałe przygotowanie do przyszłej, samodzielnej pracy zawodowej.

Ruch spółdzielczy zrósł się z edukacją okresu międzywojennego tak mocno, że doszło do powstania szkół stricte spółdzielczych, którym poświęcony jest rozdział piąty recenzowanej pracy. Ten nowy typ szkoły zawodowej miał szansę rozwinąc się dopiero w latach trzydziestych, gdyż wcześniej - mimo licznych inicjatyw ruchu spółdzielczego - brak było woli politycznej, aby wspomnianym inicjatywom mogła stać się zadość. Przedstawiając plany i programy nauczania szkół spółdzielczych, Autorka czyni jednocześnie dwa istotne i bardzo interesujące spostrzeżenia. Jedno z nich dotyczy błędnego uregulowania prawnego, w wyniku którego, aż do 1938 r. szkoły te funkcjonowały na zasadzie szkół eksperymentalnych, co na pewno nie służyło ich wzrostowi ilościowo-jakościowemu. Druga z refleksji odnosi się do fundamentalnego znaczenia oddolnego ruchu spółdzielczego, którego prężność w działaniu przy organizowaniu omawianych szkół niejednokrotnie okazywała się bardziej decydująca niż wytyczne ministerialne.

Rozdział szósty pracy prezentuje proces realizacji wychowania spółdzielczego w seminariach nauczycielskich oraz w szkołach wyższych i akademickich. Szczególne znaczenie należy przypisać kształceniu uspółdzielczeniu w seminariach nauczycielskich. Szkoły te, przez umiejętnie skonstruowane programy nauczania i wychowania, nie tylko rozwijały ideę spółdzielczości na terenie samych placówek, ale i przygotowywały swoich podopiecznych do prowadzenia tego typu działalności w przyszłym miejscu pracy. Równie istotne było propagowanie ruchu spółdzielczego w środowisku nauczycielskim, co stanowi przedmiot rozważań ostatniego rozdziału pracy. Podstawową rolę odgrywał tu przede wszystkim Związek Nauczycielstwa Polskiego przy ofiarnym wsparciu polskich organizacji spółdzielczych. Widząc w nauczycielu naturalnego sprzymierzeńca w procesie zaszczepiania młodemu pokoleniu postaw kooperacyjnych, ruch spółdzielczy nie 
szczędził wysiłków, aby wesprzeć pedagogów w ich działaniu edukacyjnym. Autorka wymienia i charakteryzuje szereg przedsięwzięć, które miały służyć rozpowszechnieniu idei spółdzielczości wśród nauczycieli: organizowanie specjalnych kursów dla opiekunów spółdzielni uczniowskich, sprawowanie nad spółdzielniami opieki gospodarczo-instruktażowej oraz propagowanie edukacji spółdzielczej na łamach prasy i w obrębie spółdzielczych księgarni nauczycielskich.

Rozprawę zamykają uwagi końcowe, które - przez umiejętne wyeksponowanie najważniejszych wniosków badawczych - stanowią doskonałe podsumowanie całej pracy.

Odbiorca recenzowanej książki pozostanie z pewnością pod wrażeniem nakładu pracy Autorki, która przekłada się nie tylko na liczbę stron (a tych jest - bez bibliografii 520), ale na zdolność przełożenia wielowątkowej problematyki na spójną i logiczną narrację. Pracowitość Autorki podkreślają dodatkowo podstawy źródłowe pracy. Dość wspomnieć, że sama bibliografia zajmuje w recenzowanej pracy aż 47 stron i obejmuje m.in. materiały źródłowe archiwalne, czasopisma, dzienniki urzędowe, księgi pamiątkowe, sprawozdania szkolne oraz pamiętniki.

Uwagę zwraca również strona edytorska książki. Staranność wydania, dbałość o przypisy, a także zamieszczone ilustracje z pewnością ułatwiają odbiór publikacji. Pewien niedosyt budzi natomiast brak indeksu osobowego, który pozwoliłby odbiorcy na szybkie odszukanie w treści książki interesujących go osób.

Praca E. Magiery przez wnikliwe zgłębienie problematyki nie tylko na trwałe wpisuje się w historiografię prac o edukacji spółdzielczej, ale i stanowić będzie punkt odniesienia dla wszystkich przyszłych rozpraw na ten temat.

Joanna Król

\section{Philippe Ariès, Historia dzieciństwa. Dziecko i rodzina w czasach ancien régi- me'u, Wyd. Aletheia, Warszawa 2010, ss. 335}

W subdyscyplinie, którą jest historia wychowania sięganie do francuskiej literatury przedmiotu ma długą tradycję. W należącym do klasyki podręczniku Stanisława Kota, Historia wychowania tych odniesień jest wiele, pojawiają się m.in. nazwiska historyków, takich jak np. G. Boissier, H.J. Leblanc, M. Fournier. Pamiętamy również oszałamiający erudycją cykl wykładów H.-I. Marrou w Historii wychowania w starożytności (1969), czy należące do klasyki opracowanie A. Joberta poświęcone KEN (1979), ze wskazaniem przedwojennego stanu źródeł historycznych, co było szczególnie cenne dla późniejszych badaczy, którzy mogli zebrać materiały rozproszone i przetrzebione w wojennej zawierusze.

W latach trzydziestych XX w. we Francji zespół francuskich historyków skupionych wokół czasopisma naukowego Annales d'histoire économique et sociale (Roczniki historii ekonomicznej $i$ społecznej) stworzył nowy styl uprawiania historiografii, w którym zerwano z dominacją historii politycznej, większy nacisk kładąc na konteksty społeczne, 